\title{
Pengaruh Latihan Keterampilan Sosial dan Psikoedukasi Keluarga terhadap Peningkatan Kreatifitas dan Bakat Anak Autisme Spectrum Disorder (ASD)
}

\author{
Yeni Suryaningsih, Aliyatunnisa, Larasati Cahya Volytania
}

\author{
Fakultas Ilmu Kesehatan, Universitas Muhammadiyah Jember, Jl. Karimata \\ No. 49 Jember, Jawa Timur, Indonesia \\ Email: yeni@unmuhjember.ac.id
}

$\begin{array}{ll}\text { Diterima tanggal } & : \text { 03 Februari } 2020 \\ \text { Direvisi tanggal } & : \text { 10 Maret } 2020 \\ \text { Dipublikasikan tanggal } & : \text { 11 Juni } 2020\end{array}$

\begin{abstract}
Abstrak
Latar Belakang dan Tujuan: Autism spectrum disorder (ASD) dapat menyebabkan gangguan kreativitas dan bakat sehingga membutuhkan stimulasi peningkatan kreativitas dan bakat. Tujuan penelitian ini adalah untuk menganalisis pengaruh pelatihan keterampilan sosial dan psikoedukasi terhadap peningkatan kreativitas dan bakat ASD di SLB Kabupaten Jember.

Metode: Desain penelitian menggunakan eksperimen semu non randomized pretest-post test dengan kelompok pembanding. Teknik sampling menggunakan purposive sampling. Jumlah sampel 21 responden. Instrumen pengukur daftar evaluasi ada tiga kelompok yaitu pelatihan keterampilan sosial (G1), pendidikan psiko (G2), pelatihan keterampilan sosial dan pendidikan psiko (G3). G1 memiliki perbedaan tingkat kreativitas dan bakat.

Hasil: Level maksimum 8,33 dan level minimum 4,17. G2 memiliki perbedaan tingkat kreativitas dan bakat. Level maksimum 6,95 dan level minimum 2,77. G3 memiliki perbedaan tingkat kreativitas dan bakat. Level maksimum 23,61 dan level minimum 11,11. Pada uji analisis Wilcoxon $(\alpha<0,05)$ G1 memiliki $\mathrm{p}=$ 0,016, G2 memiliki $\mathrm{p}=0,017, \mathrm{G} 3$ memiliki $\mathrm{p}=0,018$. Pada analisis Kruskal Wallis $(\mathrm{p}=0,001<\alpha=0,05)$. Analisis Post Hocin Kruskal Wallis dengan MannWhitney memiliki nilai $\mathrm{p}=$ minimum $0,002(<\alpha=0,01)$.

Simpulan dan Implikasi: Latihan keterampilan sosial dan psikoedukasi keluarga dapat meningkatkan kreativitas dan bakat Autism Spectrum Disorder (ASD) pada anak sekolah. Dengan demikian latihan keterampilan sosial dapat digunakan sebagai intervensi keperawatan untuk meningkatkan kreatifitas dan bakat anak ASD.
\end{abstract}

Kata Kunci: ASD; Gangguan spektrum autisme; Latihan keterampilan sosial; Psikoedukasi keluarga

Sitasi: Suryaningsih Y, Aliyatunnisa, Volytania LC. (2020). Pengaruh latihan keterampilan sosial dan psikoedukasi keluarga terhadap peningkatan kualitas dan bakat anak autisme spectrum disorder (ASD). The Indonesian Journal of Health Science. 12(1), 1-10

Copyright: (C) 2020 Suryaningsih et al. This is an open-access article distributed under the terms of the Creative Commons Attribution License, which permits unrestricted use, distribution, and reproduction in any medium, provided the original author and source are credited.

Diterbitkan Oleh: Universitas Muhammadiyah Jember

ISSN (Print): 2087-5053

ISSN (Online): 2476-9614 


\begin{abstract}
Background and Aim: Autism spectrum disorder (ASD) can cause impaired creativity and talent, thus requiring stimulation to increase creativity and talent. The purpose of this study was to analyze the effect of social skill training and psychoeducation on increasing creativity and talent for ASD in SLB Jember Regency.

Method: Method of the study was quasi experimental non randomized pretestposttest with comparison group. Sampling technique was used purposive sampling. Number of samples 21 respondents. There are three groups to measure the evaluation list, namely: Social skill training (G1), psychoeducation (G2), social skill training and psychoeducation (G3). G1 had difference level of creativity and talent.

Results: The level maximum was 8,33 and level minimum was 4,17. G2 had difference level of creativity and talent. The level maximum was 6,95 and level minimum was 2,77. G3 had difference level of creativity and talent. The level maximum was23,61and level minimum was 11,11. In Wilcoxon analyze test ( $\alpha<$ 0,05) G1 had $p=0,016$, G2 had $p=0,017$, G3 had $p=0$,018. In Kruskal Wallis analyze $(p=0,001<\alpha=0,05)$. Post Hocin Kruskal Wallis with MannWhitney had minimum $p$ value $=0,002(<\alpha=0,01)$.

Conclusion: The three group could increasing creativity and talent of Autism spectrum disorder (ASD) in school-children. Thus, social skills training can be used as a nursing intervention to increase creativity and talents of ASD children.
\end{abstract}

Keywords: ASD; Autism spectrum disorder; Family psychoeducation; Social skill training

\section{PENDAHULUAN}

Autism Spectrum Disorder (ASD) dapat mengganggu kreatifitas dan bakat anak secara normal (Smart \& Rose, 2010). Prevalensi autis semakin meningkat diketahui pada tahun 2015 sekitar satu per 250 anak mengalami gangguan spektrum Autis. Tahun 2015 diperkirakan terdapat kurang lebih 12.800 anak penyandang autisme dan 134.000 penyandang spektrum Autis di Indonesia (Sopiandi, 2017). Data dari Pendidikan Dasar dan Pendidikan Menegah Kementrian Pendidikan dan Kebudayaan pada tahun 2019 diketahui di Kabupaten Jember terdapat 193 anak penyandang ASD yang tersebar di beberapa SLB yang ada di Kabupaten Jember.
Manifestasi ASD salah satunya adalah gangguan kreatifitas dan bakat yang dapat menimbulkan depresi (National Institude of Mental Health, 2011). Kreativitas dan bakat memiliki peran sentral dalam pembelajaran dan perkembangan anak secara keseluruhan, maka akibat dari kreativitas dan bakat yang tidak dikembangkan akan mempengaruhi pertumbuhan dan perkembangan anak tersebut (Darmawan \& Hardi, 2011).

Latihan keterampilan sosial dan psikoedukasi keluarga perlu diberikan pada anak ASD (Yusuf, Bahiyah \& Isna, 2017). Tujuannya supaya anak autis dapat meningkatkan kreatifitas dan bakat, kontrol diri, kemampuan diri dan kemampuan sosial dalam aktifitas 
bersama di lingkungan sekolah dan rumah. Psikoedukasi keluarga diajarkan pada keluarga, dengan harapan keluarga juga mampu meningkatkan komunikasi dan kreatifitas serta bakat pada anak autis di rumah (Kneisl, 2004).

Beberapa

membuktikan

keterampilan sosial dan psikoedukasi keluarga dapat meningkatkan kreativitas dan bakat pada anak ASD, namun penelitian yang menggabungkan kedua intervensi tersebut belum pernah dilakukan. Penggabungan dari kedua intervensi ini diharapkan akan menjadi sebuah upaya berkelanjutan untuk meningkatkan kemampuan kreatifitas dan bakat anak autis, baik di lingkungan sekolah maupun di lingkungan rumahnya. Sehingga kemampuan kreatifitas dan bakat akan berhasil dengan baik dan mampu beradaptasi, serta anak bisa diterima di lingkungan sosialnya baik itu di sekolah maupun di rumah.

\section{METODE PENELITIAN}

Penelitian ini menggunakan metode quasi eksperimental non randomized pretest posttest with comparison group design dengan intervensi latihan keterampilan sosial dan psikoedukasi keluarga. Penelitian dilakukan untuk mengetahui pengaruh latihan keterampilan sosial dan psikoedukasi keluarga terhadap kemampuan kreatifitas dan bakat anak autis di SLB Kabupaten Jember. Penilaian dengan menggunakan lembar evaluasi dilakukan sebanyak 2 kali yaitu sebelum dan sesudah melakukan intervensi.

Subjek penelitian yang memenuhi kriteria inklusi yang telah ditetapkan berjumlah 21 responden. Dibagi dalam tiga kelompok: latihan keterampilan sosial (G1), psikoedukasi keluarga (G2), serta latihan keterampilan sosial dan psikoedukasi keluarga (G3). Penelitian dilakukan selama 20 hari, mulai tanggal 2 Juni - 22 Juni 2019. Frekuensi pemberian intervensi tiap 2 hari sekali dengan durasi 45 menit tiap pertemuan.Perbedaan hasil dari pre dan post test dianggap sebagai hasil dari treatment yang dilakukan. Instrumen penelitian menggunakan lembar evaluasi yang telah dilakukan uji validitas menggunakan korelasi product moment dengan nilai $\mathrm{r}=0,786$ 0,995. Sedangkan uji reliabilitas menggunakan Koefisien Reliabilitas dengan chronbach alpha didapatkan $\mathrm{r}=0,995$.

Analisis univariat dan bivariat menggunakan uji Wilcoxon, sedangkan uji multivariat menggunakan Kruskal Wallis dengan Post Hoc Mann-Whitney.

\section{HASIL}

Hasil penelitian diketahui bahwa karakteristik anak ASD yang menjadi responden dari segi usia sebagian besar berada dalam rentang usia 9-10 tahun sejumlah 12 responden (57\%), jenis kelamin hampir seluruhnya laki-laki sebanyak 18 responden $(85,7 \%)$. Sedangkan karakteristik caregiver dari segi usia hampir setengahnya berada dalam rentang usia 40-50 tahun sejumlah 9 responden $(42,9 \%)$, tingkat pendidikan sebagian besar SMA sebanyak 11 responden $(52,38 \%)$, hampir seluruhnya caregiver bekerja yaitu sebanyak 17 responden $(80,06 \%)$, dan sebagian besar jumlah anak yang dimiliki adalah 2 anak 
sebanyak 13 responden $(61,91 \%)$ (Tabel 1).

Analisis normalitas data diketahui berdistribusi normal dengan hasil kelompok latihan keterampilan sosial (pre $p$ value $=0,010$, post $p$ value $=0,002)$ pada kelompok psikoedukasi keluarga (pre $p$ value $=0,002$, post $p$ value $=$ 0,002), pada kelompok latihan keterampilan sosial dan psikoedukasi keluarga ( pre $p$ value $=0,010$, post $p$ value $=0,188)$ maka kesimpulannya distribusi data tidak normal (Tabel 2). Dengan demikian dilakukan uji nonparametrik dengan menggunakan uji wilcoxon untuk bivariat dan uji kruskal wallis dengan post hoc mann-whitney. Berdasarkan hasil uji dengan menggunakan levene's test diketahui bahwa significancy test homogeneity of variance menunjukkan nilai $\mathrm{P}$ value $\geq 0,05$ yang berarti tidak terdapat perbedaan yang signifikan antar kelompok, artinya data homogen.

$$
\text { Perbedaan kemampuan }
$$

kreatifitas dan bakat sebelum mendapatkan perlakuan latihan keterampilan sosial mempunyai nilai tertinggi 63,89 dan kemampuan kreatifitas dan bakat tertinggi sesudah dilakukan latihan keterampilan sosial adalah 68. Perbedaan peningkatan tertinggi adalah 8,33 dan perbedaan terendah mempunyai nilai 4,17. Sebelum dilakukan penelitian enam orang responden mempunyai kategori kemampuan kreatifitas dan bakat kurang dan satu orang responden mempunyai kemampuan kreatifitas dan bakat cukup dengan nilai 63,28. Setelah dilakukan latihan keterampilan sosial enam orang responden mempunyai kategori kemampuan kreatifitas dan bakat kurang dan satu orang responden dengan kemampuan kreatifitas dan bakat cukup nilai 68.

Perbedaan kemampuan kreatifitas dan bakat sebelum mendapatkan perlakuan psikoedukasi keluarga mempunyai nilai tertinggi 59,72 dan kemampuan kreatifitas dan bakat tertinggi sesudah dilakukan psiko-edukasi keluarga adalah 63,89. Perbedaan peningkatan tertinggi adalah 6,95 dan perbedaan terendah mempunyai nilai 2,77 . Sebelum dilakukan penelitian seluruh responden mempunyai katagori kemampuan kreatifitas dan bakat kurang, setelah dilakukan psikoedukasi keluarga satu orang responden masuk dalam katagori kemampuan kreatifitas dan bakat cukup dengan nilai 63,89 .

Perbedaan kemampuan kreatifitas dan bakat sebelum mendapatkan perlakuan latihan keterampilan sosial dan psikoedukasi keluarga mempunyai nilai tertinggi 59,72 dan kemampuan kreatifitas dan bakat tertinggi sesudah dilakukan latihan keterampilan sosial dan psikoedukasi keluarga adalah 73,61. Perbedaan peningkatan tertinggi adalah 23,61 dan perbedaan terendah mempunyai nilai 11,11 . Kemampuan kreatifitas dan bakat sebelum dan sesudah dilakukan latihan keterampilan sosial dan psikoedukasi keluarga didapat hasil peningkatan kemampuan kreatifitas dan bakat setelah dilakukan perlakuan, diketahui sebelum dilakukan perlakuan 7 orang $(100 \%)$ mempunyai katergori kurang dan sesudah dilakukan latihan keterampilan sosial dan psikoedukasi keluarga didapatkan hasil peningkatan pada kemampuan kreatifitas dan bakat, setelah dilakukan perlakuan tapi dalam 
pengklasifikasian didapatkan satu orang responden (14,29\%) mempunyai kategori kemampuan kreatifitas dan bakat kurang dan enam orang mempunyai katagori ke-mampuan sosialisasi cukup $(85,71 \%)$.

Hasil analisis dengan menggunakan uji Wilcoxon $(\alpha<$ 0,05), didapatkan kemampuan kreatifitas dan bakat meningkat dari sebelum dilakukan latihan keterampilan sosial, dengan nilai $\mathrm{p}$ pada latihan keterampilan sosial = 0,016, pada psikoedukasi keluarga $\mathrm{p}$ $=0,017$ dan pada latihan keterampilan sosial dan psikoedukasi keluarga $\mathrm{p}=0,018$. Nilai $\mathrm{p}$ terbaik terdapat pada latihan keterampilan sosial dengan nilai $\mathrm{p}=0,016$ berarti terdapat perbedaan yang signifikan antara sebelum dan sesudah perlakuan pada latihan keterampilan sosial (Tabel 3).

Analisis Kruskal Wallis diperoleh nilai $\mathrm{p}=0,001$ dengan demikian terdapat perbedaan kemampuan kreatifitas dan bakat antara ketiga kelompok (latihan keterampilan sosial, psikoedukasi keluarga serta latihan keterampilan sosial dan psikoedukasi keluarga (Tabel 4). Analisis Post Hoc pada Kruskal Wallis dengan menggunakan Mann-Whitney didapatkan hasil $\mathrm{K} 1: \mathrm{K} 3$ dan $\mathrm{K} 3: \mathrm{K} 2$ mempunyai nilai $\mathrm{p}$ terkecil yaitu 0,002 , secara statistik tidak terdapat perbedaan pada kelompok tersebut karena $\alpha<0,001$ (Tabel 5).

Tabel 1. Karakteristik Responden $(\mathrm{n}=21)$

\begin{tabular}{lcc}
\hline Karakteristik & Frekuensi & Persentase (\%) \\
\hline Anak & 12 & 57 \\
Usia & 5 & 23,8 \\
$\quad$ 9-10 Tahun & 4 & 19,2 \\
$\quad$ 10-11 Tahun & & \\
$\quad$ 11-12 Tahun & 18 & 85,7 \\
Jenis Kelamin & 3 & 14,3 \\
$\quad$ Laki-laki & & \\
$\quad$ Perempuan & & \\
Caregiver & 2 & 9,5 \\
Usia & 7 & 33,3 \\
$\quad$ 20-30 Tahun & 9 & 42,9 \\
$\quad>$ 30-40 Tahun & 3 & 14,3 \\
$\quad$ 40-50 Tahun & & 52,38 \\
$\quad$ 50 Tahun & 11 & 4,76 \\
Tingkat Pendidikan & 1 & 42,85 \\
$\quad$ SMA & 9 & 80,06 \\
$\quad$ Diploma III & & 19,04 \\
$\quad$ Sarjana & 17 & 4,76 \\
Pekerjaan & 4 & 61,91 \\
$\quad$ Bekerja & & 33,33 \\
Tidak Bekerja & 1 & \\
Jumlah Anak & 7 & \\
1 & & \\
2 & & \\
3 & & \\
\hline
\end{tabular}


Tabel 2. Analisis Normalitas Latihan Keterampilan Sosial dan Psikoedukasi Keluarga Anak Autism Spectrum Disorder

\begin{tabular}{lcccc}
\hline & $\begin{array}{c}\text { Kovarian } \\
(\mathrm{n}=<30 \%)\end{array}$ & $\begin{array}{c}\text { Rasio } \\
\text { Skewness }(\mathrm{n}=- \\
2 \text { s.d 2) }\end{array}$ & Rasio Kurtss & Shapiro Wilk \\
\hline Pre & & & & \\
K1 & 8,96 & 2,647 & 3,0649 & 0,010 \\
K2 & 7,579 & 2,923 & 3,577 & 0,002 \\
Post & & & & \\
K1 & 6,486 & 2,919 & 3,577 & 0,002 \\
K2 & 7,009 & 2,920 & 3,600 & 0,002 \\
\hline
\end{tabular}

Tabel 3. Analisis Kemampuan kreatifitas dan bakat pada Kelompok Anak dengan Latihan Keterampilan Sosial

\begin{tabular}{lc}
\hline Kemampuan Aktivitas dan Bakat & $P$ Value \\
\hline Latihan Keterampilan Sosial & 0,016 \\
Pre (7) & \\
Post (7) & \\
Psikoedukasi Keluarga & 0,017 \\
Pre (7) & \\
Post (7) & \\
Latihan Keterampilan Sosial dan Psikoedukasi & 0,018 \\
Keluarga & \\
Pre (7) & \\
Post (7) & \\
\hline
\end{tabular}

Tabel 4. Hasil Analisis Kruskal Wallis pada Latihan Keterampilan Sosial, Psikoedukasi Keluarga serta Latihan Keterampilan Sosial dan Psikoedukasi Keluarga

\begin{tabular}{cccc}
\hline Kelompok & N & Indeks Brinkman & Nilai P \\
\hline K1 & 7 & $(56,94-68)$ & 0,001 \\
K2 & 7 & $(52,77-63,89)$ & \\
K3 & 7 & $(59,72-73,61)$ & \\
\hline
\end{tabular}

Tabel 11. Hasil Analisis Post Hoc pada Kruskal Wallis dengan menggunakan Mann-Whitney pada Perlakuan Latihan Keterampilan Sosial, Psikoedukasi Keluarga serta Latihan Keterampilan Sosial dan Psikoedukasi Keluarga

\begin{tabular}{rrrr}
\hline Kelompok & $\mathrm{N}$ & Nilai \\
\hline $\mathrm{K} 1: \mathrm{K} 2$ & $7: 7$ & 0,090 & \\
$\mathrm{~K} 1:$ K3 & $7: 7$ & 0,002 & \\
$\mathrm{~K} 3:$ K2 & $7: 7$ & 0,002 & \\
\hline
\end{tabular}

\section{PEMBAHASAN} kemampuan kreatifitas dan bakat antara sebelum dan sesudah dilakukan latihan keterampilan sosial, meskipun dalam pengkatagorian masih masuk dalam katagori yang sama antara sebelum dan sesudah latihan keterampilan sosial. Kondisi 
ini tidak beda dengan hasil penelitian yang menemukan bahwa latihan keterampilan sosial dapat meningkatkan kemampuan kreatifitas dan bakat pada anak autis (Croen, et. $\mathrm{Al}$, 2011). Melalui latihan keterampilan sosial yang dilakukan secara berkala bisa meningkatkan kemampuan kreatifitas dan bakat anak autis (Arter, DeMatteo, Faseiana, Panihamus, Sworen-Parise, 2012).

Stuart dan Laraia (2011) menyatakan bahwa latihan keterampilan sosial didasarkan pada keyakinan bahwa keterampilan dapat dipelajari dan dilakukan oleh semua orang. Latihan keterampilan sosial merupakan sebuah metode berdasarkan prinsip-prinsip sosial dan menggunakan teknik perilaku bermain peran, mencontohkan cara perilaku sosial yang baru supaya dipelajari anak autis dengan cara memberikan bimbingan, praktek secara langsung kepada anak autis dengan cara bimbingan dan demonstrasi dan umpan balik setelah melakukannya dalam upaya meningkatkan kemampuan seseorang dalam menyelesaikan masalah di lingkungan sosialnya (Kneisl, Trigoboff \& Wilson, 2004)

Sikap caregiver berpengaruh terhadap peningkatan kreativitas dan bakat. Karena sikap caregiver memiliki pengaruh yang cukup kuat terhadap peningkatan kreativitas dan bakat anak autism spectrum disorder dibandingkan dengan orang lain. Hasil penelitian ini sesuai dengan penelitian Aryani (2001) yang menyatakan bahwa orang tua yang menerima anaknya, akan lebih memperhatikan perkembangan anak dan memberikan kesempatan serta sarana interaksi yang dapat membantu anak dalam mengembangkan kreativitas dan bakat. Penerimaan caregiver mempunyai sumbangan efektif terhadap peningkatan kreativitas dan bakat. Tobroni (2013) menyatakan ibu yang menerima anaknya akan mengembangkan hubungan yang penuh kehangatan dan membuat proses interaksi antara ibu dan anak berjalan dengan baik dan lancar sehingga ibu akan dapat memberikan rangsangan bagi aspek-aspek perkembangan anak ke arah yang lebih baik.

Hasil yang didapatkan mengalami peningkatan kemampuan kreatifitas dan bakat yang tidak signifikan dibandingkan dengan dilakukan perlakuan latihan keterampilan sosial sendiri oleh peneliti. Hal ini disebabkan karena sebagian besar caregiver bekerja sehingga waktu luang untuk melakukan latihan keterampilan sosial di rumah sangat terbatas (Dahlan, 2012). Latihan keterampilan sosial membutuhkan waktu khusus 45-60 menit perhari karena terjadi peningkatan kreatifitas dan bakat yang signifikan pada waktu tersebut (Rosdakarya, et.al, 2014; Maag, 2006).

Latihan keterampilan sosial yang diajarkan tidak berpengaruh secara signifikan terhadap peningkatan kemampuan kreatifitas dan bakat dibandingkan dengan psikoedukasi keluarga. Penyebabnya adalah suasana yang kurang mendukung karena diajarkan di lingkungan sekolah dengan lingkungan yang agak ramai dan frekuensiyang kurang. Anak Autisme Spectrum Disorder (ASD) butuh kedekatan yang lebih dalam pelaksanaan latihan keterampilan sosial. Anak Autisme Spectrum 
Disorder (ASD) juga membutuhkan latihan yang berulang-ulang dan pendampingan dari peneliti supaya bisa mempraktekkan kreativitas dan bakat yang dimiliki pada lingkungan sosialnya. Pada psikoedukasi keluarga juga dibutuhkan pendampingan pada saat keluarga mengaplikasikan latihan keterampilan sosial kepada anak Autisme Spectrum Disorder (ASD), supaya hasil yang didapatkan bisa maksimal.

Ketiga kelompok yang dilakukan perlakuan tidak terbukti kalau latihan keterampilan sosial dan psikoedukasi keluarga lebih baik dalam meningkatkan kemampuan kreatifitas dan bakat anak Autisme Spectrum Disorder (ASD), dibandingkan dengan ketiga kelompok. Dengan demikian ho diterima tidak terbukti kalau kombinasi latihan keterampilan sosial dan psikoedukasi keluarga lebih baik dari latihan keterampilan sosial saja atau psikoedukasi keluarga saja terhadap peningkatan kemampuan kreatifitas dan bakat Anak Autisme spectrum disorder (ASD) di SLB Kabupaten Jember.

Autisme Spectrum Disorder (ASD) tidak bisa mendapatkan intervensi secara langsung dari dua arah, disebabkan karena kondisi anak autis yang terbiasa sendiri sehingga dibutuhkan kedekatan yang berbeda dalam melakukan intervensi. (Kandaswamy, 2016). Edgington, et al (2016) menunjukkan perbedaan yang tidak signifikan antara kelompok intervensi dan kelompok kontrol, jadi psikoedukasi keluarga dirasa kurang sesuai untuk anak dengan gangguan mental tanpa diberikan perlakuan yang lain yang mendukung perkembangan mental anak. Adam et al (2012) menunjukkan bahwa psikoedukasi keluarga ini sama seperti treatment lainnya tidak menunjukkan hasil yang signifikan pada beberapa kondisi, perlu adanya modifikasi lain. Psikoedukasi keluarga sangat membantu jika digunakan pada beberapa diagnose (Townsend, 2009) saat keluarga mengetahui kondisi kesehatan dari salah satu anggota keluarga yang mengalami sakit, mereka akan dengan segera membantu penatalaksanaan dirumah (Townsend, 2009). Namun masih dibutuhkan pendampingan dalam melaksanakan intervensi jadi tidak hanya keluarga saja yang melatih perlu adanya peneliti atau pelatih yang sebenarnya.

\section{SIMPULAN}

Latihan keterampilan sosial dan psikoedukasi keluarga dapat meningkatkan kemampuan kreatifitas dan bakat anak Autisme Spectrum Disorder (ASD) di SLB Kabupaten Jember. Intervensi latihan keterampilan sosial yang diberikan serta psikoedukasi terhadap keluarga membentuk sebuah pola yang menetap sebagai stimulasi terhadap kreatifitas dan bakat anak ASD.

\section{SARAN}

Latihan keterampilan sosial dan psikoedukasi keluarga dapat diberikan pada anak ASD sebagai salah satu intervensi keperawatan. Namun untuk mendapatkan hasil yang optimal, dibutuhkan latihan ketrampilan sosial dan psikoedukasi keluarga dengan frekuensi yang lebih banyak dalam pelaksanaannya. Selain itu juga dibutuhkan evaluasi dan koreksi yang mendalam supaya hasil yang didapatkan sesuai dengan yang diinginkan. 


\section{DAFTAR PUSTAKA}

Adam, Dixon, Downing, Farlane, Lucksted. (2012). Recent developments in family psychoeducation as an evidence-based practice. Journal of Marital and Family Therapy. (38)

Arter, DeMatteo, Faseiana, Panihamus, Sworen-Parise. (2012). Social skills training for young adults with autism spectrum disorder: Overview and Implications for Practice. Journal Of National Teacher Education .5(1)

Aryani (2011). Pengaruh psikoedukasi keluarga terhadap dukungan psikososial keluarga pada anggota keluarga dengan penyakit kusta di Kabupaten Pekalongan.Universitas Indonesia, Jakarta

Croen, L. A., Grether, J.K., Yoshida, C.K., Odouli, R., dan Hendrick, V. (2011). Antidepressant Use During Prenancy and Childhood Autism Spectrum Disorders. Arch Gen Psychiatry, 68(11): 1104-1112

Darmawan, H., \& Hardi, I. (2011) Cinta kasih jurus jitu mendidik anak: pengalaman 36 tahun. Jakarta: Pustaka Sinar Harapan.

Dinas Pendidikan Kabupaten Jember. (2019). Data anak penderita autis di Kabupaten Jember.

Edgington, L., Hill, V. \& Pellicano, E. (2016). Research in Developmental Disabilies The design and implementaon of a CBT-based intervenon for sensory processing difficules in adolescents on the ausm spectrum. Research in Developmental Disabilies, 59, pp.221-233. Available at: hp://dx.doi.org/10.1016/j.ridd .2016.09.004.

Kandaswamy, R.. (2016). Damage Caused by Repeve Behavior Modificaon Based Therapies in Ausm and the Myth of " Early Intensive Intervenon " in Ausm The Myth of " Early Intervenon " in Ausm with " Intensive " Methods and Applicao. Journals The Neurological, pp.2-4.

Kneisl, C.R., Wilson, H.S. \& Trigoboff, E. (2004). Contemporary psychiatric mental health nursing. New Jersey : Pearson Prentice Hall

Maag (2006). Social skills training for students with emotional and behavioral disorders a review of review studi Metaanalysis. Journal of Behavioral Disorder 32(1)

Nasional Instute of Mental Health. (2011). A Parent's Guide to Ausm Spectrum Disorder., pp.3-9.

Pamungkas, A. P. (2015). Pelatihan keterampilan pengasuhan autis untuk menurunkan stres pengasuhan pada ibu dengan anak autis. EMPATHY Jurnal Fakultas Psikologi, 3(1), 1-22 Rahayu, E. W., Karini, S. M., \& Karyanta, N. A. (2014). Hubungan antara kematangan emosi dan dukungan emosi dengan penerimaan pada ibu yang memiliki anak autis di SLB Negeri Semarang. Jurnal Ilmiah Psikologi Candrajiwa, 3(3), 171-184

Rosdakarya Bourgondien, Mary E. Van; Dawkins, Tamara; \& 
Marcus, Lee. (2014).

Families of Adults with

Ausm Spectrum Disorder.

New York. Journal of Ausm

and Developmental

Disorders, 42, 1818-1826.

Smart dan Rose. 2010. Anak cacat bukan kiamat. Yogyakarta: Katahati

Sopiandi, R. (2017). Pengetahuan gizi ibu, pola makan, asupan zat gizi dan status gizi anak dengan Autism Spectrum Disorder (ASD). ARGIPA. Vol. 2, No. 2: 45-53

Stuart, G.W \& laraia, M.T. (2005). Principle and practice of psichiatric nursing. $\left(8^{\text {th }}\right.$ ed). Philadelphia, USA: Mosby, Inc

Tobroni. (2013). Menggali Kreativitas Seni pada Anak Berkebutuhan Khusus. HUMANIORA, Vol 4. No 1

Townsend, M.C (2009). Psychiatric mental helath nursing $\left(6^{\text {th }}\right.$ ed). Philadelphia: F.A. Davis Company

Yusuf, A., Bahiyah, K., \& Isna, L. (2017). The corelation of lovaas method aplication with the obedient of autism child. Jural Ners, 4, 24-30. 